\title{
Mapping Students' Phonological Problems in Pronouncing English Sounds: A Study on Speakers of Local Languages in West Nusa Tenggara
}

\author{
Arafiq Arafiq* \\ English Department \\ Universitas Mataram \\ Mataram, Indonesia \\ arafiq@unram.ac.id
}

\author{
Kamaludin Yusra \\ English Department \\ Universitas Mataram \\ Mataram, Indonesia \\ kamaludin@unram.ac.id
}

\author{
Agus Saputra \\ English Department \\ Universitas Mataram \\ Mataram, Indonesia \\ agussaputra@unram.ac.id
}

\begin{abstract}
Learning English to EFL learners must always be challenging since it requires not only the willingness for learning, but also students' awareness of the phonological differences between the students' mother tongue on one hand and English as the target language on the other. One of the potential problems is phonology. This study aims at describing the students' phonological problems in pronouncing English segmental sounds. There are 10 students' each of local language speakers taken as the sample in this study. Data is gained by using phonological test. In the test, the sample were asked to pronounce English words of which the sounds do not exist in each local language phonology. The result reveals that, there two English sounds found to be a problem encountered by Sasak students, both of which are consonants. The sounds are fricative labiodental voiceless /f/ as in /f $\Lambda$ ðər/ pronounced /f $\Lambda$ ðər / in inital position, /st $\Lambda \mathrm{f} /$ pronounced $/ \mathrm{st} \Lambda \mathrm{p} /$, and $/ \mathrm{h} \Lambda \mathrm{lf} /$ pronounced $/ \mathrm{h} \Lambda \mathrm{lp} /$ in the last position and labiodental fricative voiced $/ \mathrm{v} /$ as in /varieisən/ pronounced /parieisən/ in initial position, /weiv/ pronounced /weip/ in the last position. This mispronunciation was encountered by 2 out of 10 students. For Bimanese students, consonants alveolar plosive voiced $/ \mathrm{d} /$, alveolar plosive voiceless $/ \mathrm{t} /$, and open middle central vowel /ə/ were mispronounced with labiodental plosive voiced /D/, labiodental plosive voicelss /T/, and midle front vowel /e/ respectively. This mispronunciation was encountered by 4 out of 10 students. What seems interesting is that the evidence found in Sumbawan students which shares the same as in both neighboring students. There are 2 students out of 10 who mispronounced the labiodental fricative voiceless /f/ and labiodental fricative voiced $/ \mathrm{v} /$ with bilabial plosive voiced $/ \mathrm{p} /$ as Sasak students did. Meanwhile, the other 2 students mispronounced the open middle central vowel /a/ with middle front vowel /e/ as encountered by Bimanese students. This result is expected to draw a pedagogical implication for English learners to speakers of three local languages in West Nusa Tenggara.
\end{abstract}

Keywords - mispronunciation, English students, local language speakers, West Nusa Tenggara

\section{INTRODUCTION}

English is a language of 21 st century [1]. It is the language of global communication and science. In Indonesia, English has taugth from elementary to university level. However, the competence of Engish learners is still low at all levels of education [2]. For most Indonesia learners, it is a chalanging subject to learn due to its phonological chracteristic which is different from Indonesian and their mother tounges (MT). Several researches have suggested that the influence of pholonogical aspects of the MT in EFL learner is significant. Swan and Smith [3], for example stated that the failure in English learning was not due to the unsystematic afford of learning, but to the reflection of phonological inventory, the rule of sound combinations, and stress and intonation pattern of the MT of the learners. Renaldi, Stefani, and Gulo [4] found that the absence of English phonological segments of ESL learners' in their MT phonological segments contributes much on the pronunciations of standard English words. Similarly, Keshawarz and Khamis [5] implied that MT played in important role in the field of Second Language Acquisation (SLA).

What causes the failure of English Language Learning in Indonesia is now seen to have much been effected by the phonological chracteristics of the learners' MT. The difference between the phonological characteristics of learners' MT put on some constrains at the learners' afford in performing their English skils, especailly speaking. The negative feeling and behaviour, like affraid of being tittered, become the major cause of the failure. This is also true to the Bimanese English Learners [6].

In conclussion, several studies, ([7]; [8] ; [9]) have proved the phonological structure of learners' MT has an impact on their L2 acquisation and contribute a lot to the negative transfere of the target langage (TL) pronuncation compared to the grammar and vocabulary.

\section{METHOD}

This descriptive study was done by recruiting 30 English students from English Department of Faculty of Teacher Training and Education, Mataram University as the sample. These students were from 3 local language speakers in West Nusa Tenggara Province (i.e. the speakers of Sasak, Sumbawan, and Bima Language who have been learning English for several years. The data of this study were the English segmental sounds which are absent in the three local language phonology inventories as produced by the samples. The samples were asked to pronounce the words twice. At first, they were asked to read the words only, then at the second time they were asked to repeat the words as they were narrated by tape-recorded native speaker narrators. During the pronunciation test, the recorder was on to make the sounds of the languages documented. This data were transcribed both literally and phonetically. The data were analysed descriptivly with camparing the sample productions 
with the Standard English ones using Error Analisis Hypothesis introduced by Larry Selinker and friends in 1970's ([10]; [11]). This way the data can be easily identified, classified, and described.

\section{RESULTS AND DICUSSION}

All three languages phonetic inventories look different from English. Quantitatively, the number of sounds of the three local languages is less than that of English which has 24 consonants and 12 vowels [12]. This fact influences the English perfomance of the learners of the speakers of the languages. Some obvious problems encountered are narrated in the following.

\section{A. The Problems Encountered by the Sasak Learners}

There are two English sounds found to be problems by Sasak speaking learners both of which are consonants. These sounds are mispronounced by two Sasak learners from ten. The sounds are fricative labiodental voiceless /f/ and fricative labiodental voiced /v/. The followings are English words where the problematic sounds for Sasak speaking learners occure.

TABLE I. PROBLEMATIC SOUNDS FOR SASAK SPEAKING LEARNERS

\begin{tabular}{|c|c|c|c|}
\hline No & Words & $\begin{array}{c}\text { English } \\
\text { pronuncation }\end{array}$ & $\begin{array}{c}\text { Sasak } \\
\text { pronunciation }\end{array}$ \\
\hline 1 & Father & /f & /pнðər/ \\
\hline \multirow[t]{2}{*}{2} & phenomena & /fenomenə/ & /penomenə/ \\
\hline & Confortable & /kənfortebəl/ & /kənportebəl/ \\
\hline 3 & Staff & /st $\wedge f l$ & /st $\wedge p /$ \\
\hline 4 & Half & $/ \mathrm{h} \Lambda \mathrm{l} f /$ & $/ \mathrm{h} \Lambda \mathrm{l} p /$ \\
\hline 5 & Variation & /varieifən/ & /parieifən/ \\
\hline 6 & Evening & /ivining/ & /ipining/ \\
\hline 7 & Wave & /weiv/ & /weip/ \\
\hline
\end{tabular}

The above data shows how the sounds were mispronounced. Fricative labiodental voiceless /f/ as in /f $\Lambda$ ðər/ pronounced with / $p_{\Lambda}$ ðər/ and /fenomenə/ with /penomenə/ in initial position, /kənfortebəl/ pronounced with /kəmportebəl/ and /səfistikeitəd/ with /səpistikeitəd/ in the middle, /st $\Lambda f /$ pronounced with $/ \mathrm{st} \Lambda \mathrm{p} /$, and $/ \mathrm{h} \Lambda \mathrm{l} f /$ with $/ \mathrm{h} \Lambda \mathrm{l} p /$ in the last position. Meanwhile, labiodental fricative voiced $/ \mathrm{v} /$ as in /varieisən/ pronounced with /parieisən/ in initial position, /ivinin/ with /ipinin/ in the middle, and weiv/ with /weip/ in the last position.

Due to the absence of such sounds in Sasak Language, makes the learners alter the pronunciations of the words to the closest sounds in the language. Bilabial stop voiceless /p/ is the most applicable they could afford for labiodental fricative voiced and voiceless /v/ and /f/. The alternations of the sounds is drawn in the following.

TABLE II. THE ALTERNATIONS OF THE SOUNDS

\begin{tabular}{|l|c|c|c|c|}
\hline \multirow{2}{*}{} & \multicolumn{2}{|c|}{$\begin{array}{c}\text { Bilabial (Sasak } \\
\text { Language) }\end{array}$} & \multicolumn{2}{c|}{$\begin{array}{c}\text { Labiodental } \\
\text { (English) }\end{array}$} \\
\cline { 2 - 5 } & $+v$ & $-v$ & $+v$ & $-v$ \\
\hline Stop & $\mathrm{b}$ & $\mathrm{p}$ & & \\
\hline Fricative & & & $\mathrm{v}_{\mathrm{V}}$ & $\mathrm{f}$ \\
\hline
\end{tabular}

This evidance suggests that Sasak learners generalize the sounds by their place of articulations rather than manner and voicing. Keshawarz and Khamis [13], for instance found that Hausa-speaking learners mispronounced /f/ with /p/ since this sound does not exist in Hausa. Herman [14] also found that Senior High School students of Pematangsiantar in Indonesia faced difficulties in pronuncing labiodental fricative /f/ and /v/.

\section{B. The Problems Encountered by Bimanese learners}

There are 4 out of 10 Bimanese students encountered problem in pronuncing alveolar plosive voiced /d/ as in /di:k/ /lædər/, and /ri:d/ alveolar plosive voiceless /t/ as in /t $\Lambda \mathrm{sk} /$, /letər/ and /kæt/. These sound were mispronounced with labiodental plosive voiced /D/, labiodental plosive voicelss /T/. Observe the data below.

TABLE III. MISPRONOUNCED SOUND

\begin{tabular}{|c|c|c|c|}
\hline No & Words & $\begin{array}{c}\text { English } \\
\text { Pronuncation }\end{array}$ & $\begin{array}{c}\text { Bima } \\
\text { Language } \\
\text { Pronunciation }\end{array}$ \\
\hline 1 & Deak & /di: $\mathrm{k} /$ & /Di:k/ \\
\hline 2 & Ladder & /lædər/ & /læDər/ \\
\hline 3 & Read & /ri:d/ & /ri:D/ \\
\hline 4 & Task & $/ t \Lambda \mathrm{sk} /$ & $/ T \Lambda \mathrm{sk} /$ \\
\hline 5 & Letter & /letər / & /leTər / \\
\hline 6 & Cat & /kæt/ & $/ \mathrm{kæT} /$ \\
\hline
\end{tabular}

The alternation of alveolar plosive voiceless $/ \mathrm{t} / \mathrm{l}$ and alveolar plosive voiced /d/ are labiodental plosive voiced /D/, labiodental plosive voicelss /T/ which exist in the Bima Language phonology. The following shows the features of the sounds and illustrate how the alternations were made.

TABLE IV. THE ALternations SOUND

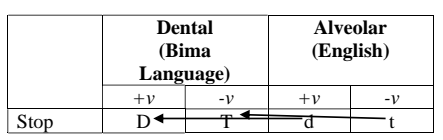

The choice of dental stop voiceless /T/ for alveolar stop voicelss /t/ and dental stop voiced /D/ for alveolar stop voiced /d/ are the most possible alternations which the Bimanese learners could make as they share very close point of articulations.

Meanwhile, 3 students mispronounced half open middle central vowel /ə/ and half open middle central-tensed vowel /3:/ as in /mathər/ and /posibəl//3:rn/ and /g3:rl/ with open middle front vowel /e/ and close front vowel /i/ respectively as shown in the following.

TABLE V. MISPRONOUNCED HALF OPEN MIDDLE CENTRAL

\begin{tabular}{|c|l|l|l|}
\hline No & Words & \multicolumn{1}{|c|}{$\begin{array}{c}\text { English } \\
\text { pronuncation }\end{array}$} & $\begin{array}{r}\text { Bima } \\
\text { Language } \\
\text { pronunciation }\end{array}$ \\
\hline 1 & Mother & /m $\Lambda$ thər/ & /m $\Lambda$ ther/ \\
\hline 2 & Possible & /posibəl/ & /posibel/ \\
\hline 3 & Girl & /g3:rl/ & /g3:rl/ \\
\hline 4 & Bird & /b3:d/ & /bir:d/; /ber:d/ \\
\hline 5 & Earn & /3:rn/ & /i:rn/;/e:rn/ \\
\hline
\end{tabular}

The sounds the Bimanese speaking learners could make for open middle central vowel / / / and half open middle central-tensed vowel /3:/ are open middle front vowel /e/ and close front vowel /i/. These two sounds were pronounced interchangebly depends on the letter they were used to 
represent them. The following shows how the mispronunciations were made.

TABLE VI. MISPRONUNCIATIONS

\begin{tabular}{|l|c|c|}
\hline & $\begin{array}{c}\text { Front } \\
\text { (Bima } \\
\text { Language) }\end{array}$ & $\begin{array}{c}\text { Central } \\
\text { (English) }\end{array}$ \\
\hline Close & i & \\
\hline Close-Mid & e & 2 $3:$ \\
\hline Half Open-Mid & & \multicolumn{2}{|c|}{} \\
\hline
\end{tabular}

The alternations for half open-middle central vowel /a/ and half open-middle central-tensed vowel was mispronounced with open middle front vowel /e/. Meanwhile, middle central-tensed vowel /3:/ was mispronounced with both open middle front vowel /e/ and close front vowel /i/. The alternatios of the sounds much depends on the letters the sounds are represented. Rahal [15], found that Tunisian English learners encountered mispronunciation of half open-middle central vowel /ə/ or schwa sound.

\section{The Problems encountered by Sumbawan learners}

What seems interesting is that the evidance found in Sumbawan shares the same mispronunciation sounds in both neighbour languages. There are 2 of 10 Sumbawan students encountered the mispronunciations of labiodental fricative voiceless /f/ and labiodental fricative voiced /v/ with bilabial plosive voiced $/ \mathrm{p} /$ as encountered by Sasak students as shown in the following.

TABLE VII BILABIAL PLOSIVE VOICED

\begin{tabular}{|c|l|l|l|}
\hline No & \multicolumn{1}{|c|}{ Words } & $\begin{array}{c}\text { English } \\
\text { pronuncation }\end{array}$ & $\begin{array}{c}\text { Sumbawan } \\
\text { pronunciation }\end{array}$ \\
\hline 1 & Flat & $/$ flaet/ & $/$ plaet / \\
\hline 2 & Phenomena & $/$ fenomenə/ & /penomenə/ \\
\hline 3 & Wave & $/$ weiv/ & $/$ wei $p /$ \\
\hline 4 & Staff & $/$ st $\Lambda$ fl & $/$ st $\Lambda \mathrm{p} /$ \\
\hline 5 & Half & $/ \mathrm{h} \Lambda \mathrm{f} /$ & $/ \mathrm{h} \Lambda$ l $p /$ \\
\hline 6 & Variation & $/$ arieisən/ & $/$ parieisən/ \\
\hline 7 & Identify & /aidentifai/ & /identipai/ \\
\hline
\end{tabular}

Bilabial stop voiceless $/ \mathrm{p} /$ is the only applicable sound that Sumbawan speaking learners could afford for both labiodental fricative voiced and labiodental fricative voiceless /v/ and /f/ as the Sasak sepaking learners could. The alternations of the sounds is drawn in the following.

TABLE VIII. THE ALTERNATIONS OF THE SOUNDS

\begin{tabular}{|l|c|c|c|c|}
\hline \multirow{2}{*}{} & \multicolumn{2}{|c|}{$\begin{array}{c}\text { Bilabial } \\
\text { (Sumbawan) }\end{array}$} & \multicolumn{2}{c|}{$\begin{array}{c}\text { Labiodental } \\
\text { (English) }\end{array}$} \\
\cline { 2 - 5 } & $+v$ & $-v$ & $+v$ & $-v$ \\
\hline Stop & $\mathrm{b}$ & $\mathrm{p}$ & & \\
\hline Fricative & & & $\mathrm{v}$ & $\mathrm{f}$ \\
\hline
\end{tabular}

The other 2 students encountered the problems in pronouncing half open middle central vowel /o/ with open middle front vowel /e/ and half open middle central-tensed vowel /3:/ with close front vowel /i/ as Bima speaking learners did. The following are English words which Sumbawan speaking learners misprounced as Bima speaking learners also did.
TABLE IX. SUMBAWAN SPEAKING LEARNERS MISPROUNCED

\begin{tabular}{|c|l|l|l|}
\hline No & Words & $\begin{array}{c}\text { English } \\
\text { pronuncation }\end{array}$ & $\begin{array}{c}\text { Sumbawan } \\
\text { pronunciation }\end{array}$ \\
\hline 1 & Mother & /mıthər/ & $/$ m 4 ther / \\
\hline 2 & Possible & /posibəl/ & $/$ posibel / \\
\hline 3 & Girl & /g3:rl/ & $/$ g3:rl / \\
\hline 4 & Bird & /b3:d/ & /bir:d/; /ber:d/ \\
\hline 5 & Earn & /3:rn/ & /i:rn/; /e:rn/ \\
\hline
\end{tabular}

Like Bimanese speaking learners, the pronunciation that Sumbawan could make for open middle central vowel /a/ and half open middle central-tensed vowel /3:/ are open middle front vowel /e/ and close front vowel /i/. The following shows how the mispronunciations were made.

\section{TABLE X. MisPRONUNCIATIONS}

\begin{tabular}{|l|c|c|}
\hline & $\begin{array}{c}\text { Front } \\
\text { (Sumbawan) }\end{array}$ & $\begin{array}{c}\text { Central } \\
\text { (English) }\end{array}$ \\
\hline Close & i & \\
\hline Close-Mid & e & ə $3:$ \\
\hline $\begin{array}{l}\text { Half } \\
\text { Open-Mid }\end{array}$ & & \\
\hline
\end{tabular}

Just like the evidance found in Bima sepaking learners, the alternations for half open-middle central vowel /ə/ and half open-middle central-tensed vowel was mispronounced with open middle front vowel /e/. Meanwhile, middle central-tensed vowel /3:/ was mispronounced with both open middle front vowel /e/ and close front vowel /i/. This evidance may suggests the relationship and the contact between the two neighbhour language to Sumbawan, Sasak Language from the west and Bima Language from the East.

\section{CONCLUSION}

All speakers of West Nusa Tenggara Province encountered problems in pronuncing particular English sounds. That the sounds do not exist in the languages is believed to be the causes of the problems. For Sasak speaking learners, fricative labiodental voiceless /f/ and labiodental fricative voiced /v/ were mispronounced with stop bilabial voiceless /p/. Meanwhile, consonants alveolar plosive voiced $/ \mathrm{d} /$, alveolar plosive voiceless $/ \mathrm{t} /$, and open middle central vowel /ə/ were mispronounced with labiodental plosive voiced /D/, labiodental plosive voicelss $/ \mathrm{T} /$, and midle front vowel /e/ respectively by Bimanese speaking learners. Suprisingly, Sumbawan speaking learners shares the same mispronunciation of the sounds found in both neighboring languages. The labiodental fricative voiceless /f/ and labiodental fricative voiced /v/ were mispronounced with bilabial plosive voiced $/ \mathrm{p} /$ as Sasak students did, the open middle central vowel /ə/ and half open middle central-tensed vowel /3:/ were mispronounced with midle front vowel /e/ as Bimanese speaking learners did.

From this finding, it is suggested that English sounds should be learned with approaches where phonetic and accustic sound production is put into practice. The negative tranfer of MT sound production to EFL is still significant/emanent that drawing pedagical implications for English learners to speakers of three local languages in West Nusa Tenggara Province is essential to do in the future. 


\section{REFERENCES}

[1] Zohud, N. W. I. "Teaching Strategies and Their Role on Students' Engagement in Learning English." (Thesis) Faculty of Graduate Studies: An-Najah National University Palestine. 2015.

[2] Puspedik Kemendikbud. Laporan Hasil Ujian Nasional. Retrieved from https://puspendik.kemdikbud.go.id/hasil-un/. 2019

[3] Swan, M \& Smith, B. "Learner English : A Teacher's Guide to Interference and Other Problems" Modern Language Journal 72 (4), 461, 2018. Retrieved from https://epdf.pub/learner-english-a-teachersguide-to-interference-and-other-problems.html.

[4] Renaldi, A., Stefani, R. P. \& Gulo, I. "Phonological Difficulties Faced by Students in Learning English" Proceedings of the Fourth International Seminar on English Language and Teaching (ISELT 4), 2016.

[5] Keshavarz, M. H., and Khamis A., M. "An investigation into pronunciation problems of Hausa-speaking learners of English" International Online Journal of Education and Teaching (IOJET), 4(1). 61-72, 2017.

[6] Arafiq, Mu'adz., H., Yusra, K. "Pemetaan Fonologi Bahasa Bima dan Tantangannya Terhadap Pembelajaran Bahasa Inggris bagi Penutur Bahasa Bima." (Unpublished) Laporan Penelitian Dana PNBP Universitas Mataram Tahun 2016.

[7] Sedighi, S. "An account of Iranian EFL pronunciation errors through L1 transfer." Iranian Journal of Applied Linguistics Studies, 2(2), $197-214,2010$

[8] Tsojon, I. Y., \& Aji, Y. N. "Pronunciation Problems Among Jukun (Wapan) English Speakers" European Journal of Research and Reflection in Arts and Humanities, 2(1), 6-12, 2014.

[9] Zhanmig, W. "Review of the influence of L1 on L2 acquisition" Studies in Literature and Language, 9(2), 57-60, 2014

[10] Lightbown, Patsy M. and Nina Spada. How Languages are Learned. Oxford: Oxford University Press, 2011.

[11] Khansir, A. A. "Error Analysis and Second Language Acquisition" Theory and Practice in Language Studies Vol. 2, No. 5, . 1027-1032, Academy Publishe: Finland, May 2012

[12] Musk. Vowels and Consonants of Eglish. Department of Culture and Education. Linkopings Universitet. 2019. Retrieved from https://old.liu.se/ikk/english/files/Course\%20Webpages/english3/1.206147/CompendiumVowelsConsonantsofEnglish.pdf

[13] Herman. "Students' Difficulties in Pronuncing the English Labiodental Sounds" Communication and Linguistics Studies. 2 (1), 1-5: Science and Publishing Group, 2016.

[14] Rahal, A. "The fossilized pronunciation of the schwa sound /e/ in the speech of Advanced Tunisian English learners: Problems and causes". International Journal of Humanities and Cultural Studies (IJHCS) 1(1), 1-5, 2014. 